first month and 1 per cent for subsequent months; once a quarter has been infected and freed from infection, the probability of re-infection increases with the number of previous infections.

An examination of copper as a growth promoter in pigs indicated that either pure copper sulphate or a mineral mixture providing copper sulphate at about $0 \cdot 1$ per cent of the weight of the fattening meal gives an increased rate of growth in fattening pigs; even at this high level there is no suggestion that copper is toxic to fattening pigs. No benefit was obtained either in live-weight gain or efficiency of food utilization when the floors of styes were kept artificially warmed in winter.

Another inquiry revealed that, when measured in terms of the milk production of grazing cows, meadow fescue has consistently outyielded, in each of two seasons, both perennial ryegrass and cocksfoot. An investigation into the production of saliva by the cow showed that a milking cow, on a normal diet, in the course of a day probably produces more than ten gallons of saliva, a large proportion of which appears to be secreted while she is eating.

There are indications that the œstrogenic isoflavone, biochanin A, recently isolated from red clover, is present in other clovers, and also, probably to a lesser extent than in red clover, in timothy, Italian ryegrass, meadow fescue and cocksfoot. This substance is present (along with the related cestrogen genistein) in subterranean clover. It is, however, doubtful whether, in current agricultural practice in Britain, cestrogens in pasture plants have any significant effect on milk production or other physiological activities of livestock.

Claims made abroad that the addition of menadione to raw milk, or to the food of lactating cows, caused a marked improvement in keeping quality of milk could not be substantiated. In certain circumstances, menadione in the milk appeared to have a deleterious effect in cheesemaking. Its use as an additive to milk, in any event illegal, is also undesirable on technological grounds.

It was found that the gut contents of chicks about to hatch are sterile; but those kept without food after hatching develop a flora in a fow hours. When recently hatched chicks are fed, a balanced gut flora is established within two days.

The whitening of milk which occurs at temperatures above $60^{\circ} \mathrm{C}$. increases in magnitude with the acidity of the milk, and increases with additions of soluble proteins. On heating milk further, the rate of browning seems to depend only on the $p H$, the rate increasing with alkalinity. Milk sterilized in a plate heat-exchanger at $135^{\circ} \mathrm{C}$. is whitened in colour and not browned.

The young calf was shown to be a poor converter of carotene to vitamin A. This seems to be the case for all very young animals examined, namely, calves, rats and chicks. Conversion efficiency increases with age.

A significant improvement in growth-rate and a reduction in the incidence and severity of scouring were frequently brought about in young calves by giving them an antibiotic supplement to the diet. The effect, however, appears to be much smaller where the calves are born and reared under good conditions of health and management.

An interesting finding was that the sense of smell seems to be less sensitive than the sense of taste in discriminating between flavours in dairy products, even when the observers concerned think otherwise.

\section{SICKLE CELL GENE DISTRIBUTION}

$\mathrm{D}^{\mathrm{n}}$ R. H. LEHMANN has recently published two papers. The first is about the distribution of the sickle cell gene (Eug. Rev., 46, 3 ; 1954); the second deals with the Andaman Islands (St. Bartholomew's Hospital J., 59, 99; 1955). From the observation of Herrick in 1910 of a case of chronic anæmia in a Negro student characterized by 'sickle'shaped red blood cells, investigations have continually proceeded. It was first shown by Huck in 1923 that sickle cell anæmia behaved as a simple Mendelian character and that heterozygotes or carriers could be identified by the anaerobic incubation of blood, whereupon fresh normal blood would take on the sickle appearance. The chemical aspect was studied by Pauling (1950), who found that sickle cells contain a hæmaglobin which differs in its physical propertios from normal adult hæmaglobin. Normal and sickle hæmaglobins could be separated by electrophoresis.

The incidence of the 'sicklæmic' gene was high in American Negroes (about 10 per cent); but other races did not seem to possess it.

In 1944 and 1945 Evans initiated a large-scale survey on the frequency of occurrence of sicklæmia in West Africa, and found a 20 per cent incidence in 561 Africans from Nigeria, the Cameroons, Gambia and the Gold Coast.

Further large-seale observations were made in West Africa by Findley and his collaborators, the results showing a frequency not very different from those found by Evans. Sickle cells were reported from East Africa in 1945 by $H$. C. Trowell and from Northern Rhodesia (12 per cent) in 1946 by Beet. Altmann in 1945 reported their absence in South African Negroes.

In 1949 Lehmann and Milne examined nearly 5,000 individuals of twenty-four different tribes in Uganda. In the Nilotic tribes the incidence of sicklæmia was strikingly homogeneous and varied from 21 to 28 per cent.

Foy and his colleagues (1954) surveyed the southern Sudanese and found that the Nilotics fall into two groups, one allied to the Uganda Nilotics and the other with Half Hamitic affinities.

The former group had a high sicklæmia incidence and the latter usually a low one $(0 \cdot 8-3.9$ per cent).

In Bantu-speaking tribes sicklæmia varied in incidence, from 2 per cent in the Bairu tribe to 45 per cent in the Baamba-a secluded pigmoid tribe in the forest of the Mountains of the Moon.

The distribution of the sickle gene in Uganda seems to be connected with the invasion route of the pastoral Half Hamites, being lowest among the Bantu along that route and highest in the lessaccessible swamps, jungles and mountain tops.

Allison (1954) put forward another explanation of the variable incidence of the sickling gene in the Bantu. It is assumed that the invaders occupied the healthiest and least malarious zones of the country. It is further assumed that the sickling gene has a selective advantage in malarious tracts, the $S$ hæmaglobin being less desirable to the malaria parasite than the normal $A$. hæmaglobin. It follows that the sickling gene will be most frequent in malarious surroundings. This theory is supported by the fact that the Half Hamitic tribes all live in the least malarious areas of Uganda and that adjacent Bantu tribes share both low malaria incidence and low sickling. But as Herman points out, the question is 
complicated by the fact that a large admixture of physical Hamitic features in a Bantu tribe-presumably through intercrossing-is also connected with low sickling.

These researches led to the possibility that the distribution of the sickling and other blood genes (Rhesus, $A B O, M N S$, etc.) could as genetical markers throw light on to Haddon's theory of a Neolithic immigration from India into Africa.

Accordingly, in 1952 the Nuffield Foundation financed an expedition to South India, and extensive observations of the incidence of sickling were made by Dr. Lehmann in a number of communities.

The gene was found among the Veddoids, of the Nilgiris-primitive peoples who until recently were food gatherers with no knowledge of agriculture. The incidence in both Pancyans and Irulas was very high--more than 30 per cent-while in the Tamils, Telegus and Canarese the gene was not found.

Further reference is made to the prevalence of the sickling gene in the Veddoids of Arabia, and also in Greece, and to the distribution of other blood genes in relation to migratory movements of populations in past times.

Dr. Lehmann, in a brief summary, assigns high incidence of the sickling gene to three major factors : (1) the anthropological derivation of the population ; (2) genetic regulation such as a high mutation-rate or balanced polymorphism (Neel, 1953); (3) a social situation which produces inbreeding.

The discussion is not on the whole well balanced, and no reference is made to a possible high coexistence between malaria and sickling in either South India, Arabia or Greece, though data are probably available. The fact that the highest sickling-rates are found in the socially lowest stratum of a population seems to be significant only in relation to gene introgression from other communities.

The second paper contains a general account of the Andaman Islanders. The results of the blood groupings did not point to any connexion between the Andamanese and the African peoples, but rather indicated relationship with the inhabitants of the Admiralty Islands and New Guinea.

S. C. Hartand

\section{NATURAL INSECTICIDES IN WEST AFRICA}

A SURVEY of the natural insecticides used by the peoples of West Africa has been made by Dr. F. R. Irvine (Col. Plant and Animal Prod., 5, No. 1).

The question of the toxicity to man of preparations used as insecticides is important where food crops are concerned; many of these African insecticides are also used for catching fish. The action of some of them is merely to stupefy the fish which, when afterwards eaten, are quite innocuous.

West African insecticides fall naturally into three groups, those containing (1) alkaloids; (2) rotenone or its close relatives; and (3) resins and oils. A few others are useful on account of an acid, tannin, or latex.

Of those containing alkaloids, the tobacco plants, Nicotiana tabacum and $N$. rustica, both probably long known as insecticides to West Africans, are in common commercial use. Species of Datura, especially $D$. metel, the active principle of which is hyoscine or scopolamine, are used on floors to destroy a bad pest-the jiggers or sand fleas which bore into the feet.

The powdered seeds of certain Annona have been reported from the tropics both as insecticides and as fish poisons. Water suspensions of the seeds of A. reticulata produced a high percentage of kill among the green bugs, Lecanium.

Another and more powerful alkaloid is found in the bark of the sassy bark or red water tree, Erythrophloeum guineense, which is used for destroying fish, game animals and rats, and as ingredient in arrow poison. The active compound is erythrophleine, which resembles digitalis in its action on the human body. In West Africa insecticidal use is made of the leaves, which are put with stored corn to keep insects away.

A leguminous shrub, Sophora tomentosa, contains in its seeds about $2 \cdot 0$ per cent of cytisine. This alkaloid has proved to be a relatively potent insecticide to adult Aphis rumicis, resembling nicotine in its physiological action.

The leaves of the Indian nim tree, Melia azedarach, have been successfully used on the Gold Coast for pre. venting infestation of cocoa beans by the insect Ephestia. Elsewhere they have been found to be repellent to locusts, and it is claimed that extracts can be effectively applied for the protection of fruit, vegetable and cereal crops.

Many plants contain rotenone or allied compounds. About two dozen spocies of Tephrosia are used as fish poisons in various parts of the world and some of them are used as insecticides. Among these, $T$. vogelii is of particular interest. Its pounded leavos and pods, thrown on water, stupefy fish in such numbers that its use had to be prohibited in certain areas. The fish so caught are quite edible. The seeds, too, have been proved by Wilbaux to be toxic to molluses. (Here may be a substitute, probably innocuous to pets and song birds, for the material used in poison bait to combat the ubiquitous slug in British home gardens.) The leaves, when dried, are widely used by Africans for destroying human insect and other parasites, for example, head-lice and fleas. They are used by Europeans in Nyasaland against dog ticks and fleas and in Rhodesia and elsewhere against lice. Tephrosia, in at least five species, contains rotenone and other compounds in common with Derris and Lonchacarpus.

Another well-known fish poison is the leguminous shrub, Mundulea sericea, which kills rather than stupefies; it is risky to eat the fish afterwards. In Mysore, India, the pulverized bark of $M$. sericea has been used against various pests and the bark, roots and seeds as fish poison. East Africans declare the pounded bark to be sufficiently potent to kill man, and put into the water, they say, it drives away crocodiles. Though only small quantities of rotenone have been found in the air-dried bark, its toxicity is thought to be due to the presence of allied compounds. Certain East African tests showed it to be almost as lethal as Derris roots.

Allied to Derris is the leguminous genus Lonchocarpus. In South America this produces the wellknown insecticide, cube, which, like derris, is a piscicide.

Some of the preparations which contain resins or oils are toxic by contact methods while others are effective as fumigants.

Certain Dichapetalum species are poisonous : their seeds to man, rats and parasites, their leaves to 